\section{Planeetta haastaa aikuiskasvatuksen tutkijat}

Aaro Harju \& Anja Heikkinen (toim.) (2016). Adult Education and the Planetary Condition. Vapaa Sivistystyö \& Sivistystyön Vapaus ja Vastuu. ISBN 978-952-5349-27-6 (PDF, www.vapausjavastuu.fi/wp-content/uploads/2016/06/ Planetary_condition_060716_print.pdf); 978-952-5349-28-3 (painettu)

ARTIKKELIKOKOELMASSA tutkijat kuvaavat planeetan tilaa aikuiskasvatuksen tutkimuksen eri näkökulmista. Se perustuu keväällä 2015 Tampereella järjestettyyn pohjoismaiseen aikuiskasvatuksen tutkimuskonferenssiin, johon pyydettiin artikkeleita samalla teemalla. Julkaisun otsikko herättää kysymyksiä. Mitä tarkoitetaan planeetan tilalla: ilmastonmuutosta, populismia, eriarvoistumista, kuudetta massasukupuuttoa vai jotakin ihan muuta? Entä miten aikuiskasvatuksen tutkimus liittyy planeetan tilaan?

Kirjan toimittajat toteavatkin heti aluksi, että konferenssiin lähetetyt artikkelit eivät juuri vastanneet kutsuun tarjota planetaarisen näkökulman aiheita. Yksi kirjan, tai oikeammin sitä taustoittavan konferenssin, ansioista onkin teemavalinta. On selvää, että kaikki tutkimus ei voi fokusoida planetaarisella mittakaavalla, mutta kun yksittäiset tutkimukset kootaan ajankohtaisen, yleisesti kiinnos-

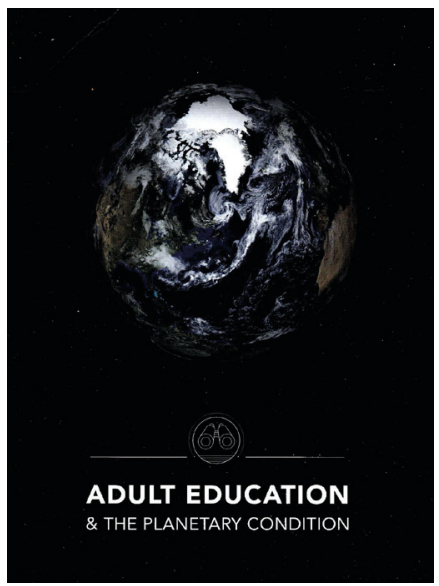

tavan teeman alle, kokonaisuus ja planetaarisuus hahmottuvat. Niinpä lukija saa vastauksen kysymyksiinsä kuin varkain kirjaa lukiessa.

Esipuheessa toimittajat myös nostavat esiin keskustelun puutteen pohjoismaisessa aikuiskasvatuksessa: kukaan ei oikeistaan ole tiennyt, mitkä asiat pohjoismaisessa aikuiskasvatustutkimuksessa ovat tarkasteltavina. Siten 
julkaisu on omiaan avaamaan keskustelua tutkijayhteisöä kiinnostavista teemoista.

Julkaisuun valittujen artikkelien pohjalta toimittajat ehdottavat tutkimusta yhdistäviksi globaaleiksi tai planetaarisiksi teemoiksi ainakin postkolonialismia, transnationalismia, kestävää kehitystä ja antroposeeniä. Antroposeeni on tutkijoiden epävirallisesti nimeämä uusi geologinen epookki, jota leimaa ihmisen vaikutus ympäristöön.

Teemat on helppo tunnistaa kirjaa lukiessa. Lukijan helpotukseksi artikkelit on jaoteltu aiheittain neljään kappaleeseen, jotka käsittelevät planetaarista teemaa koulutuspolitiikan, työelämän, aikuisopiskelijan itsensä ja kestävyyden näkökulmista.

\section{LAAJA KATTAUS}

Toimittajien valitsemat artikkelit ovat julkaisun toinen ansio. Niissä kuvataan yhtäältä koulutuksen länsimaista hegemoniaa, joka pahimmillaan toimii kuin vieraslaji tukahduttaen paikallisen monimuotoisuuden ja perinteet. Toisaalta liikutaan uteliain ottein tieteen ja taiteen välimaastossa ja esimerkiksi perehdytään ihmisen luontoyhteyden ja symbolis-antropologiseen pedagogiaan perustuvan ruumiillisen meditaation suhteeseen.

Artikkelien aiheet vaihtelevat nuorten työllistymisen edistämisestä sukupuolten väliseen tasa-arvoon, vapaan sivistystyön poliittisten ohjauskeinojen haasteista kansainvälisten korkeakouluopiskelijoiden sopeutumiseen, ja kiinalaisen guanxi-verkostoitu- miskulttuurin huomioon ottamisesta koulutusyhteistyössä yksilön voimaantumiseen ja merkityksellisyyden tunteen tärkeyteen.

Kirja on suunnattu laajemmalle yleisölle kuin vain planetaarisesta mittakaavasta kiinnostuneille. Se on samanaikaisesti sekä laaja että hyvinkin yksityiskohtainen kattaus. Julkaisu luo monipuolisen kuvan aikuiskasvatuksen tutkimuksen mielenkiinnon kohteista sekä osoittaa, että alan tutkimusaiheet ovat ajankohtaisia, käytännöllisiä, ja lopulta hyvin planetaarisia.

Vaikka julkaisun toimittajat esittävät neljä kattoteemaa, jotka kumpuavat aiheista, luonnontieteilijätaustaisen lukijan mieleen nousee viides ydinteema: luonnon monimuotoisuus, jonka heikkeneminen on yksi keskeisimpiä planetaarisia haasteita. Kirjan artikkeleista kuitenkin heijastuu erityisesti ihmisen aiheuttama uhka kulttuuriselle monimuotoisuudelle. Kulttuurievoluutio ja sen luoma monimuotoisuus on yksi lajimme sopeutumiskyvyn, ja siten menestyksen, perusta. Kyky kulttuuriseen kehittymiseen ja heikoista huolehtimiseen ovat auttaneet lajiamme valloittamaan koko maapallon, ja nousemaan osittain jopa luonnonvalinnan yläpuolelle.

\section{ONGELMAT JA RATKAISUT}

Artikkelit havahduttavat ymmärtämään, että uhattuna ei todellakaan ole vain luonnon monimuotoisuus vaan myös omamme. Huojentavasti kirjoittajat tarjoavat myös ratkaisuja, jotta monimuotoisuuden heikkenemistä voidaan torjua. Mieleenpainuvimpia, ja myös kestävyys- ja ympäristökasvatuksen diskursseissa usein esiin nousevia, ratkaisuja ovat voimaantuminen, merkityksellisyyden löytäminen, yksilöllisten tai paikallisten piirteiden kunnioittaminen sekä kiireettömyys.

Monimuotoisuuden ymmärtämisestä ja vaalimisesta tulee yhä tärkeämpää, kun ihmisen aiheuttamat planetaariset ilmiöt etenevät. Ilmastopakolaisuutta esiintyy jo eri puolilla maailmaa, ja pahimmissa ennusteissa edessämme ovat suuret muuttoliikkeet, joilla voi olla arvaamattomia vaikutuksia.

Vuoden 2016 pakolaistulva Pohjolaan, jos sitä sellaiseksi voi vielä edes kutsua, herätti voimakasta, kansallisuudentunteen ja nationalismin nimissä lietsottua rasistista liikehdintää. Mitä sitten kun tulijoita on satojatuhansia tai miljoonia? Voidaanko silloin enää puhua vaaleatukkaisista, sinisilmäisistä skandinaaveista, vai tuleeko meistä oman alueemme vähemmistö, alkuperäiskansa? Viimeistään silloin tuntuisi mukavalta, jos valtaapitävä hallinto kunnioittaisi ja osaisi turvata vähemmistöjen oikeuksia.

\section{TUTKIMUS TUKEE HYVINVOINTIA}

Kirjassa käsitellyt aiheet - oikeudenmukaisuus, tasa-arvo, työ ja ihmisten välinen positiivinen vuorovaikutus sekä kaikenlaisen monimuotoisuuden vaaliminen - vaikuttavat suoraan planeettamme ekologiseen tasapainoon ja sen kehittymisen suuntaan. Koulutus ja kasvatus ovat keskeisiä näiden 
asioiden edistämisessä. Vaikka monissa artikkeleissa käsitellään ikäviä sosiaalisia ilmiöitä ja haasteita, kokonaisuudesta jää myönteinen kaiku. Aikuiskasvatuksen tutkimus on vahvasti tukemassa sekä planeettamme että oman lajimme hyvinvointia.

Lukukokemukseni perusteella - viitaten tutkijakonferenssissa esitettyihin epäilyihin pohjoismai- sen keskustelun tarpeesta - haluan rohkaista tutkijoita jatkamaan ja tiivistämään yhteispohjoismaista tutkimusta ja keskustelua.

Meillä on toisillemme paljon annettavaa. Koska olemme pieniä maita, keskustelu usein kaventuu, jos sitä käydään ainoastaan oman maan rajojen sisäpuolella, joten näkökulman laajentaminen on tervetullutta. Olisikin kiinnostavaa tietää, onko Pohjoismaiden välillä eroja planetaarisen teeman aikuiskasvatustutkimuksessa, ja miten esimerkiksi kansalliset kestävän kehityksen haasteet niissä heijastuvat. Englanninkielisen julkaisun voi ladata ilmaiseksi verkosta.

MEERI KARVINEN

FM, tohtorikoulutettava Aalto-yliopisto 